\title{
Notes on Caribbean Discomycetes. V. A Preliminary Annotated Checklist of the Caribbean Pezizales ${ }^{1,2}$
}

\author{
Donald H. Pfister ${ }^{3}$ \\ INTRODUCTION
}

The following annotated checklist attempts to organize the scattered reports of the Ascomycetes in the order Pezizales from the islands of the West Indies. Many of these previously published reports are in general floras which list all the fungi from particular islands or island groups. A list of these several published floras, the islands covered and the number of Pezizales included by each author is furnished in the Appendix.

A second purpose of this list is to provide a modern deposition for the species. As many of them were reported in older publications, their generic deposition does not reflect modern encepts. Type studies have been necessary in many instances to determine the identity of these ill-defined or misplaced species.

Aside from the published accounts of species, this report is based on the examination of a series of previously unreported specimens from Jamaica provided by Dr. Richard P. Korf, as well as my own collections and field data from Puerto Rico. Thus, the list indirectly serves as an index of recent collections from Puerto Rico and Jamaica.

Dennis (10) has treated the Helotiales, inoperculate discomyectes.

\section{A BRIEF HISTORICAL ACCOUNT}

The paper by Berkeley and Curtis (j) on fungi from Cuba was the first to include a significant number of species of Pezizales. Berkeley described over 600 species from Cuba, 24 of which were operculate Discomyectes. Specialists today usually treat Berkeley's names with caution for he described a number of species more than once. Ho also used the then all inclu-

1 Manuscript submitted to Editorial Buard June 11, 1973.

2 Supported in part by National Science Foundation (irant GB-36162, and a University of Puerto Rico Faculty Research grant.

${ }^{3}$ Assistant Professor, Tropical Mycology Laboratory, Department of Biology, University of Puerto Rico, Mayagüez, Puerto Rico. The following persons generously made facilities and specimens available for this study: Dr. Paul Lentz, National Fungus Collection, Beltsville, Maryland; Drs. Clark T. Rogerson and K. P. Jumont, New York Botanical (iardens, Bronx, N. Y.; 1)r. Lorin Neveling and the staff of the Farlow Herbarium and Library of Harvard University, Cambridge, Mass.; Dr. Ponce de León, Field Museum of Natural History, Chicago, Illinois; 1)r. Richard P. Korf, Cornell University, Ithaca, N. Y. I am deeply indebted (1) Ms. Pat Fazio, Acting Curator of the Cornell Plant Pathology Herbarium, for providing specimens, packet data, and copies of unavailable literature. Dr. Korf read the manuscript and made many suggestions. Cathleen $K$. Pfister helped with the laborious tasks of examining herbarium sheets, recording data, and proofreading. 
sive Peziza for most Pezizales, also Helotiales. Assigning his species to proper modern genera consequently is a major problem and it has been necessary to study his types, as well as authentic specimens.

Patouillard described several species of Pezizales in the middle and late 19th century collected by P. R. Duss in Guadeloupe and Martinique. All these species were listed collectively in 1903 by Duss (12). Patouillard used many Berkeley names, sometimes also describing varieties of them. Examination of Berkeley's type specimens indicate that Patouillard's identifications generally were incorrect and that the new species he described were predated by other names, mostly Berkeley's. A number of Patouillard species examined are listed herein as new synonyms.

F. J. Seaver, working through the first half of the twentieth century, used generic names in a somewhat more restricted sense than Berkeley or Patouillard. He accepted both Phillipsia and Cookeina, though Peziza, Humaria, and Patella remained multi-headed demons. Seaver, unlike Berkeley and Patouillard, did much of his own collecting. His understanding of the Caribbean species undoubtedly was deeper than that of his predecessors because of this first hand familiarity. Seaver's West Indian studies are summarized in his book "The North American Cup-Fungi (Operculates)" (23) and in the "Scientific Survey of Puerto Rico and the Virgin Islands" (24).

The most recent studies of Caribbean Pezizales are those of Dennis (10, 11) in which he discusses those he collected in Jamaica and Trinidad.

\section{CLASSIFICATION AND PROCEDURE}

Family names employed herein are those accepted by Korf (15). Genera are listed alphabetically within the family and species are numbered consecutively throughout. The two suborders Sarcoscyphineae and Pezizineae are recognized in this arrangement. A synopsis of the taxa included is given in the Appendix, Table 2. For a key to genera see Korf (15).

An asterisk $(*)$ indicates the species or locality so noted is a previously unreported record. Other localities are taken from the floras listed in table 1, from recent monographs or recent collections. Complete synonymies are provided only in instances of new combinations or when a species is being synonymized for the first time.

\section{PEZIZALES}

\section{SARCOSCYPHINEAE}

Sarcoscyphaceae

\section{AUROPHORA Rifai}

1. AURophora dochmia (Berk. \& Curt. in Berk.) Rifai, Verh. K. ned. Akad. Wet. II. 57(3): 52, 1968. = Peziza dochmia Berk. \& Curt. in Berk., 
J. Linn. Soc. (Bot.) 10: 364, 1868. Cuba (type locality), Jamaica, Puerto Rico. Substrate: On dead wood and branches.

This species was described originally from Cuba together with Peziza inaequalis Berk. \& Curt. and P. hirneoloides Berk. \& Curt. The two latter species are very similar to $A$. dochmia according to Rifai (27), but without adequate material he did not reduce them to synonyms or propose new combinations for them. These species also have been treated previously as Phillipsias.

2. Phillipsia Carminea (Pat.) Le Gal, Bull. Jard. Bot. Brux. 29: 103 1959. = Sarcoscypha carminea Pat., Bull. Soc. Mycol. France 15: 205, 1899. = Peziza hirneoloides Berk. var. carminea (Pat.) Pat. in Duss, Champ. à la Guadeloupe et à la Martinique, p. 63, 1903. Guadeloupe (type locality). Substrate: On rotten wood.

Rifai (27) suggested this species belongs here. I examined the type specimen and agree. As species limits in this genus are not well defined, no new combination is proposed. Judging from the inscription on the holotype packet, Patouillard believed this species was close to if not identical with $P$. hirneoloides.

Specimens examined: Holotype: Sur Erythrina indica et d'autres bois pourris, Basse-Terre, Montéran, Trois-Riviéres, Guadeloupe, Duss (221); sur divers bois pourris, Environs de la Basse-Terre, Guadeloupe, Duss (984).

\section{COOKEINA O. Kuntze}

3. cookeina sulcipes (Berk.) O. Kuntze, Revis. Gen. Pl. 2: 849, 1891. = Peziza leptopus Pers. in Lév., Ann. Sci. Nat. III 3: 39, 1845. Cuba, Dominican Republic (type locality of $P$. leptopus), Haiti, Jamaica, Puerto Rico, Trinidad. Substrate: On dead wood.

The synonymy of $P$. leptopus is based on the examination of the type specimen by Korf (pers. comm.). This species and the one following are the most commonly collected species of the genus in the Caribbean.

4. cookeina tricholoma (Mont.) O. Kuntze, Revis. Gen. Pl. 2: 849, 1891. = Peziza hystrix Berk., Ann. Mag. Nat. Hist. II. 9: 201, 1852, [fide Rifai, (27)]. Cuba, Dominican Republic (type locality of $P$. hystrix), Grenada, Jamaica, Puerto Rico, Trinidad. Substrate: On dead wood.

5. cookeina venezuelae (Berk. \& Curt.) Le Gal, Prodr. Flore Mycol. Madagascar 4: 241, 247, 1953. = Discina epixyla Pat. in Duss, Champ. à la Guadeloupe et à la Martinique, p. 63, 1903. Jamaica, Guadeloupe (type locality of D. epixyla) Substrate: On wood and branches.

The Jamaican collections have been described by Pfister (20). Dennis (9) first suggested that D. exixyla might be a synonym. Examination of 
Patouillard's specimens proved Dennis correct. Duss (12) described a variety of this species, Peziza venezuelae var. antillarum, a synonym of Phillipsia domingensis (New synonym.)

Nanoscypha Denison

6. Nanoscypha Bella (Berk. \& Curt. in Berk.) Pfister, comb. nov. = Peziza bella Berk, \& Curt. in Berk., J. Linn. Soc. (Bot.) 10: 366, 1868. Cuba (type locality). Substrate: On rotten wood.

This specific name may be an older one for $N$. macrospora Denison. An additional species, NANOSCYPHA WATERSTONII (Seaver) comb. nov. (= Humaria waterstonii Seaver, Mycologia 31: 533, 1939) from Bermuda, differs in its 8-spored asci.

Specimens examined: Fungi Cubensis Wrightiani number 668, col. C. Wright, FH; holotype of $H$. waterstonii on seeds of Livistonia chinensis, Agri. Exp. Sta. Paget East, Nov. 28, 1938, Bermuda, F. J. Seaver and J. M. Waterston (NY).

7. HUMARIA PHYLLOGENA Seaver, Mycologia 17: 46, 1925. = Humarinia phyllogena (Seaver) Seaver, N. Amer. Cup-Fungi (Opercul.) p. 134, 1928. Puerto Rico (type locality). Substrate: Dead leaves.

This species most likely is referable to Nanoscypha. It is not a Humaria in the modern sense. Doubt as to the exact anatomical features of the species makes it preferable not to propose a new combination. The asci have 8 spores as in $N$. waterstonii.

Specimens examined: Holotype of $H$. phyllogena. On leaves, Puerto Rico, Jan. 24-April 5, 1923, F. J. Seaver and C. E. Chardón; authentic material of $N$. phyllogena. On leaves, Puerto Rico, Jan. 24-April 5, 1923, F. J. Seaver and C. E. Chardón.

8. NanOSCYPHA tetraspora (Seaver ex Seaver) Denison, Mycologia 64: 619, 1972. [ = Cookeina tetraspora Seaver in Stevenson, J. Agr. Univ. P. R. 2: 160, 1918. Nomen nudum.] = Cookeina tetraspora Seaver ex Seaver, Mycologia 17: 45, 1925. = Phillipsia tetraspora (Seaver ex Seaver) Le Gal, Prodr. Flore Mycol. Madagascar 4: 284, 1953. = Sarcoscypha tetraspora (Seaver ex Seaver) Denison, Rev. Biol. Trop. 11(1): 107, 1963. Puerto Rico (type locality). Substrate: On leaves and plant debris.

This species appears to be quite common in Puerto Rico, although previously reported from only a few collections. Pfister (19) has discussed the imperfect stage.

Specimens examined: On leaf veins and petioles of Cecropia peltata, hills above Miradero, near Mayagüez, Puerto Rico, 19. II. 1973, D. H. Pfister (DHP 451); same locality and substrate, 3. X. 1972, D. H. Pfister (DHP 420). 


\section{PHILlipsia Berk.}

9. Phillipsia carnicolor Le Gal, Prodr. Flore Mycol. Madagascar 4: 281, 1953. Trinidad. Substrate: On wood buried in soil.

Le Gal (16) described the species from Madagascar; the collection from Trinidad is that listed by Dennis (9). Both Rifai (27) and Denison (7) suggest this species might be Phillipsia hartmannii (Phill. in Cooke) Rifai.

10. Phillipsia chardoniana Seaver, Mycologia 17: 48, 1925. Puerto. Rico (type locality). Substrate: On dead wood.

This species has been synonymized with $P$. domingensis (Berk.) Berk. by Denison (7). It supposedly differs from that species in its hymenial color.

11. Phillipsia crispata (Berk. \& Curt. in Berk.) Le Gal, Prodr. Flore Mycol. Madagascar 4: 262, 1953. = Peziza crispata Berk. \& Curt. in Berk., J. Linn. Soc. (Bot.) 10: 367, 1868. Jamaica*, Cuba (type locality). Substrate: On rotten wood.

Specimens examined: On wood, near Dick's Pond, west of Hardwar Gap, near Holywell Recreation Area, St. Andrew Parish, Elev. 2,800-3,000 feet, Jamaica 11.I. 1971, R. P. Korf et al. (CUP-MJ-323); vicinity of Dick's Pond, west of Hardwar Gap, near Holywell Recreation Area and Wag Water River, St. Andrew Parish, elev. 2,800-3,000 feet, Jamaica, 10.I. 1971, R. P. Korf et al. (CUP-MJ-244).

12. PHILlipsia domingensis (Berk.) Berk., J. Linn. Soc. (Bot.) 18: 388, 1881. = Peziza domingensis Berk., Ann. Mag. Nat. Hist. II 9: 201, 1852; (type locality, Guadeloupe.) = Discina martinicae Pat., J. Bot., France 4: 199, 1892; (type locality, Puerto Rico, Trinidad.) = Peziza venezuelae Berk. \& Curt. in Cooke var. antillarum Pat. in Duss, Champ. à la Guadeloupe et à la Martinique, p. 64, 1903. = Peziza hirneoloides Berk. var. contorta Pat. in Duss, Champ. à la Guadeloupe et à la Martinique. p. 63, 1903. Cuba, Dominican Republic; (type locality, Jamaica, Martinique.) Substrate: On sticks and old wood.

Specimens examined: Holotype of $D$. martinicae, Bois des Deux-Cheux, Martinique, P. Duss (FH); holotype of Peziza venezuelae var. antillarum, sur le sol dans une Caféyère, Martinique, Duss (1881) (FH); holotype of $D$. hirneoloides var. contorta, sur un Miconia, Pointe-Noire, Guadeloupe, Duss (603) (FH).

13. PHillipsia gigantea Seaver, N. Amer. Cup-Fungi (Opercul.) p. 183, 1928. Jamaica (type locality), Puerto Rico. Substrate: On dead wood. Supposedly distinctive according to Denison (7) because of its large size (4-6 $\mathrm{cm}$ ), gelatinous texture, compact exciple, and mostly 4-spored asci.

14. PHIllipsia hiRneoloides (Berk. \& Curt. in Berk.) Berk., J. Linn. Soc. (Bot.) 18: 388, 1881. = Peziza hirneoloides Berk. \& Curt. in Berk., J. Linn. Soc. (Bot.) 10: 365, 1868. Cuba (type locality). Substrate: On rotten wood. 
According to Rifai (27) this species and the one following may properly belong to the genus Aurophora. Denison (7) places them in the genus Phillipsia. Patouillard described two varieties. One is referred to $P$. carminea; the other is a synonym of $P$. domingensis.

15. PHILlipsia INAequalis (Berk. \& Curt. in Berk.) Berk., J. Linn. Soc. (Bot.) 18: 388, 1881. = Peziza inaequalis Berk. \& Curt. in Berk., J. Linn. Soc. (Bot.) 10: 365, 1868. Cuba (type locality). Substrate: On rotten wood.

\section{SARCOSCYPHA Boud.}

16. sarcoscypha occidentalis (Schw.) Sacc., Syll. Fung. 8: 154, 1889. Jamaica. Substrate: On dead sticks and twigs in litter.

A variety of this species was described by Dennis (9) under the name Plectania occidentalis var. jamaicensis Dennis. Too few specimens of this species have been studied from Caribbean collections to be sure of the validity of this variety. The comments given by Denison (8), seem to indicate that specimens collected in the Caribbean may differ sufficiently from those collected in more temperate climates to warrant acceptance of his proposed variety.

Specimens examined: Along Lady's Mile trail to just south of Woodcutter's Gap, vicinity of Newcastle, border of St. Andrew and Portland Parishes, Jamaica, 9.I. 1971, R. P. Korf et al. (CUP-MJ-177); on twigs, Cinchona Botanical Gardens, St. Andrew Parish, elev. 4,750 feet, 8.I. 1971, R. P. Korf et al. (CUP-MJ-40, CUP-MJ-52); along Ulster Road trail, Newcastle, St. Andrew Parish, Jamaica, 9.I. 1971, R. P. Korf et al. (CUP-MJ196); on wood, Chesterville Youth Development Camp, above Newcastle, St. Andrew Parish, Jamaica, 8.I. 1971, R. P. Korf et al. (CUP-MJ-16, CUP-MJ-2); on twig, along trail to Silver Hill Gap, near Woodcutter's Gap, vicinity of Newcastle, Portland Parish, Jamaica, 9.I. 1971, R. P. Korf et al. (CUP-MJ-124).

Sarcosomataceae

\section{GaLIELLA Korf and Nannf. in Korf}

17. galielia spongiosa (Berk. \& Curt. in Berk.) Pfister. (Comb. nov.) $=$ Rhizina spongiosa Berk. \& Curt. in Berk., J. Linn. Soc. (Bot.) 10: 364, 1868. = Sarcosoma spongiosa (Berk. \& Curt. in Berk.) Le Gal, Bull. Soc. Mycol. Fr. 78: 214, 1962. Cuba (type locality). Substrate: Dead branches.

Specimen examined: ad fructices, woods, Monte Verde, Cuba, Fungi Cubensis Wrightiani number 654, C. Wright 638 (FH).

\section{PLECTANIA Fuckel}

18. Plectania Campylospora (Berk. in Hook.) Nannf. in Korf, Mycologia 49: 110, 1957. Jamaica*. 
Specimen examined: On twig, trail from Whitfield Hall to Portland Gap, to Blue Mt., border of St. Thomas and Portland Parishes, Jamaica 17.I. 1971, R. P. Korf et al. (CUP-MJ-595).

19. plectania melastoma (Sow. ex Fr.) Fuckel, Jahrb. Nass. Ver. Nat. 23-24: 324, 1870. Jamaica, Puerto Rico, Cuba. Substrate: On twigs and small branches.

20. PLECTANIA RHYTIDIA (Berk. in Hook.) Nannf. \& Korf in Korf, Mycologia 49: 110, 1957. Jamaica.

Specimens examined: Trail from Whitfield Hall to Portland Gap, to Blue Mt., border of St. Thomas and Portland Parishes, Jamaica, 17.I. 1971, R. P. Korf et al. (CUP-MJ-594); on soil, on trail between Woodcutter's Gap and ruins of Major Wallin's house, vicinity of Newcastle, Portland Parish, Jamaica, 11.I. 1971, R. P. Korf et al. (CUP-MJ-295); on twigs, vicinity of Dick's Pond, west of Hardwar Gap, near Holywell Recreation Area and Wag Water River, St. Andrew Parish, elev. 2,800-3,000 feet, Jamaica, 10.I. 1971, R. P. Korf et al. (CUP-MJ-242); on twigs, Cinchona Botanical Gardens, St. Andrew Parish, elev. 4,750 feet, Jamaica, 8.I. 1971, R. P. Korf et al. (CUP-MJ-45).

\section{PSEUDOPLECTANIA Fuckel}

21. Pseudoplectania nigrella (Pers. ex Fr.) Fuckel, Jahrb. Nass. Ver. Nat. 23-24: 324, 1870. Jamaica. Substrate: On twigs and small branches.

Specimens examined: On soil, Cinchona Botanical Gardens, St. Andrew Parish, Jamaica, elev. 4,750 feet, 8.I. 1971, R. P. Korf et al. (CUP-MJ-43); on herbaceous stems, trail between Holywell and source of Wag Water River, St. Andrew Parish, Jamaica, 10.I. 1971, R. P. Korf et al. (CUP-MJ234, 236, 199); on soil and debris, trail from Whitfield Hall to Portland Gap, to Blue Mt., border of St. Thomas and Portland Parishes, Jamaica, 17.I. 1971, R. P. Korf et al. (CUP-MJ-586); on rotten wood, trail between Freetown and Wag Water River, near Hardwar Gap, St. Andrew Parish, Jamaica, 18.I. 1971, R. P. Korf et al. (CUP-MJ-610); on duff, near Dick's Pond, west of Hardwar Gap, near Holywell Recreation area, St. Andrew Parish, elev. 2,800-3,000 feet, Jamaica, 11.I. 1971, R. P. Korf et al. (CUPMJ-315).

\section{PEZIZINEAE}

Ascobolaceae

\section{ASCOBolus ${ }^{4}$ Pers. per Hooker}

22. ASCOBOLUS CUBENsis Berk. \& Curt. in Berk., J. Linn. Soc. (Bot.) 10: 370, 1868. Cuba (type locality). Substrate: On hog dung.

1 Identifications and distribution from van Brummelen (28) unless otherwise indicated. 
The type collection is the only known collection according to van Brummelen (28).

23. ascobolus immersus Pers. ex Pers., Mycol. Eur. 1: 341, 1822. Puerto Rico. Substrate: On cow dung.

This species was reported by van Brummelen (28) from several Puerto Rican collections. It probably is found elsewhere in the Caribbean.

24. ascobolos scatigenus (Berk. \& Curt. in Berk.) Brumm., Persoonia, Suppl. 1: 159, 1967. = Peziza scatigena Berk. \& Curt. in Berk., J. Linn. Soc. (Bot.) 10: 366, 1868. Cuba (type locality), Dominica*, Dominican Republic, Jamaica, Puerto Rico, Trinidad. Substrate: On dung of various animals.

This species has been reported under several names. Ascobolus major Berk. \& Curt. and A. magnificus Dodge are the most common synonyms according to van Brummelen (28). This is the Ascobolus species most commonly collected in the Caribbean probably because of the large size of the apothecia.

Specimens examined: On cow dung, Dolphin Head, Hanover Parish, Jamaica, 22.I. 1971, R. P. Korf et al. (CUP-MJ-691); on cow dung, between Buff Bay and Annotto Bay, at mile marker 36, St. Mary Parish, Jamaica, 19.I. 1971, R. P. Korf et al. (CUP-MJ-665); on cow dung, woods and orchards near Bee House, Springfield Plantation, 7 miles from Roseau, elev., 1,200 feet, Dominica, 27.VI. 1970, R. P. Korf et al. (CUP-DO-223).

\section{IODOPHANUS ${ }^{5}$ Korf in Kimb. \& Korf}

25. iodophanus carneus (Pers. ex Fr.) Korf in Kimb. \& Korf, Amer. J. Bot. 54: 19, 1967. Puerto Rico. Substrate: On dung of various animals and on decaying debris. Specimen examined: On animal dung, Mayagüez Zoo, Mayagüez, Puerto Rico, Nov. 30, 1973, D. H. Pfister (703).

26. iodophanus testaceus (Moug. in Fr.) Korf in Kimb. \& Korf, Amer. J. Bot. 54: 19, 1967. Puerto Rico. Substrate: On decaying debris.

27. IOdophanus verRucosporus (Garaff.) Kimb., Luck-Allen, \& Cain, Amer. J. Bot. 56 (10): 1,199, 1969. Puerto Rico. Substrate: 'On ground beneath turkey roost.

\section{SACCOBOLUS ${ }^{6}$ Boud.}

28. saccobolus glaber (Pers. ex Pers.) Lamb., Fl. Mycol. Belg., Suppl. 1: 284, 1887. Cuba, Dominican Republic, Jamaica, Puerto Rico, Trinidad. Substrate: On dung of various animals.

29. SACCobolus PUertoricensis Seaver, N. Amer. Cup-Fungi (Opercul.), p. 94, 1928. Puerto Rico (type locality). Substrate: On animal dung.

5 Identifications and distribution records are from Kimbrough, Luck-Allen and Cain (13) unless otherwise indicated.

- Identifications and distribution records are from van Brummelen (28) unless otherwise indicated. 
THECOTHEUs Boud.

30. thecotheus pelletieri (Cr. \& Cr.) Boud., Hist. Class. Discom. d'Eur., p. 75, 1907. Jamaica*, Puerto Rico*. Substrate: On dung of various animals.

Specimens examined: On mule dung vicinity of Dick's Pond, west of Hardwar Gap, near Holywell Recreation Area and Wag Water River, St. Andrew Parish, elev. 2,800-3,000 feet. Jamaica, 10.I. 1971, R. P. Korf et al. (CUP-MJ-251); on cow dung, trail between Holywell and source of Wag Water River, St. Andrew Parish, Jamaica, 20.I. 1971, R. P. Korf et al. (CUP-MJ-677); on cow dung, hills above Miradero, near Mayagüez, Puerto Rico, 19.II. 1973, D. H. Pfister (D. H. P. 449).

\section{Pezizaceae}

\section{PACHYELLA Boud.}

31. Pachyella adnata (Berk. \& Curt. in Berk.) Pfister, Canad. J. Bot. (in press). = Peziza adnata Berk. \& Curt. in Berk., J. Linn. Soc., (Bot.) 10: 365, 1868. Cuba (type locality), Puerto Rico, Trinidad. Substrate: On rotten wood.

This species is known in the Caribbean only from these three islands but it is probably present on others of high elevation in the area. It also is known from North America. For complete specimen citation see Pfister (22).

32. Pachyelia babingtonir (Berk. \& Br.) Boud., Hist. Class. Discom. d'Eur., p. 51, 1907. Jamaica*. Substrate: Generally on water-soaked wood.

This species is cosmopolitan in distribution and doubtlessly will be found to occur elsewhere in the Caribbean.

Specimens examined: On water-soaked log, near Dick's Pond, west of Hardwar Gap, near Holywell Recreation Area, St. Andrew Parish, elev. 2,800-3,000 feet, Jamaica, 11.I. 1971, R. P. Korf et al. (CUP-MJ-313, 314).

\section{PEZIzA L. ex St.-Amans}

33. Peziza palmicola Berk. \& Curt. in Berk., J. Linn. Soc. (Bot.) 10: 364, 1868. Cuba (type locality). Substrate: On rotten palm.

This is a true Peziza. When the genus Peziza is thoroughly investigated, the name of this smooth-spored species probably will be found as a synonym of an older one.

34. Peziza taeniospora Pfister, (Nom. nov.) = Galactinia auriformis Pat. ex Le Gal, Prodr. Flore Mycol. Madagascar 4: 54, 1953, non Peziza auriformis Schw., Syn. Fung. Carol. Super. p. 116. 1822 [= Auricularia auriformis (Schw.) Earle]. [= Galactinia taeniospora Le Gal, Ann. Sci. Nat. (Bot.) XI 8: 100, 1947, a nomen nudum.] Trinidad. Substrate: On soil. 
Reported by Dennis (9) from Trinidad under the name G. auriformis, and properly placed in Peziza in the restricted sense of Rifai (27) and Korf (15). The name auriformis cannot be transferred to Peziza because it then would become a later homonym. The nomen nodum name used by Le Gal is thus properly applied.

Several other species of Peziza have been reported from the West Indies. Peziza is a difficult genus and identifications must be regarded as tenuous. Although other species doubtlessly occur, none are listed herein.

\section{Pyronemataceae}

\section{ALEURIA Fuckel}

35. ALeuria Bicucullata Boud., Bull. Soc. Bot. France 2: 93, 1881. = Humaria guadelupensis Pat., Bull. Soc. Mycol. France 16: 183, 1900. Guadeloupe (type locality). Substrate: On soil.

Examination of the holotype specimen of Humaria guadeloupensis indicates it to be the same as Aleuria bicucullata. Aleuria bicucullata is distinguished easily from other species in the genus by its relatively small ascospores and by their ornamentation. The ascospores are marked with cyanophilic warts and ridges as well as cup-like structures at the poles of the spores. The external surface is somewhat pustulate due to aggregations of short hyaline hairs.

Specimen examined: Holotype of $H$. guadeloupensis, sur le sol (lanc?), Capesterre (Bois du Grand Etang) Guadeloupe, Duss (1005) (FH).

\section{ANTHRACOBIA Boud.}

36. anthracobia macrocystis (Cooke) Boud., Hist. Class. Discom. d'Eur., p. 65, 1907. Puerto Rico*, Trinidad. Substrate: On burnt debris. Listed here on the basis of information furnished by Dennis (9).

Specimens examined: On burned area under Casuarina, Mona Island, Puerto Rico, Carlos Betancourt, May 26, 1973 (DHP 491).

37. anthracobia melaloma (Alb. \& Schw. ex Fr.) Boud., Bull. Soc. Mycol. France 1: 106, 1885. Jamaica, Cuba, Trinidad. Substrate: On burnt soil.

\section{ASCODESMIS van Tiegh.}

38. Ascodesmis porcina Seaver, Mycologia 8: 3, 1916. Puerto Rico (type locality). Substrate: On hog dung. Originally reported by Stevenson (25) and Seaver and Chardón (24) from Puerto Rico.

Specimen examined: On goat dung from Mona Island, Puerto Rico, 25.IX. 1973, D. H. Pfister. 
CHEILYMENIA Boud.

39. cheilymenia coprinaria (Cooke) Boud., Hist. Class. Discom. d'Eur., p. 63, 1907. Dominican Republic, Jamaica*, Puerto Rico. Substrate: On dung of various animals.

Specimen examined: On cow dung, Traveler's Rest, Silver Hill Gap on the border of Portland and St. Andrew Parish, elev. 3,000-3,250 feet, Jamaica, 8.I. 1971, R. P. Korf et al. (CUP-MJ-100).

40. Cheilymenia theleboloides (Alb. \& Schw. ex Fr.) Boud., Hist. Class. Discom. d'Eur., p. 62, 1907. Dominican Republic, Jamaica*. Substrate: On dung of various animals.

Specimen examined: On mule dung, vicinity of Dick's Pond, west of Hardwar Gap, near Holywell Recreation area and Wag Water River, St. Andrew Parish, elev. 2,800-3,000 feet, Jamaica, 10.I. 1971, R. P. Korf et al. (CUP-MJ-252).

\section{COPROBIA Boud.}

41. coprobia Granulata (Bull. ex Mérat) Boud., Hist. Class. Discom. d'Eur., p. 69, 1907. Cuba, Dominican Republic, Jamaica*, Puerto Rico. Substrate: On dung. Peziza subgranulata Berk. \& Curt. is a possible synonym.

Specimens examined: On dung of cow, along Cane River and slope of Good Hope Mountain, near Kingston, St. Andrew Parish, Jamaica, 12.I. 1971, R. P. Korf et al. (CUP-MJ-398, 408); on cow dung, trail between Barretts Gap and Corn Puss Gap, St. Thomas Parish, elev. 1,600-2,000 feet, Jamaica, 15.I. 1971, R. P. Korf et al. (CUP-MJ-503, 509, 525).

\section{coprotus Korf \& Kimb. in Kimb. and Korf}

42. coprotus aurora (Cr. \& Cr.) Kimb., Luck-Allen, \& Cain, Canad. J. Bot. 50: 961, 1972. Puerto Rico*. Substrate: On cow dung.

Specimen examined: On old cow dung with Theocotheus pelletieri, Hills above Miradero, near Mayagüez, D. H. Pfister (D. H. P. 450), 19.II. 1972.

43. Coprotus dextrinordes Kimb., Luck-Allen, \& Cain, Canad. J. Bot. 50: 962, 1972. Puerto Rico (type locality). Substrate: On cow dung. Reported by Kimbrough et al. (14).

44. coprotus disculus Kimb., Luck-Allen, \& Cain, Canad. J. Bot. 50: 962, 1972. Jamaica*. Substrate: On cow dung.

Specimens examined: On cow dung, trail between Barretts Gap and Corn Puss Gap, St. Thomas Parish, elev. 1,600-2,000 feet, Jamaica, 15.I. 1971, R. P. Korf et al. (CUP-MJ-497, 508, 511, 520, 528, 533); on cow dung, along Cane River and slope of Good Hope Mountain, near Kingston, St. Andrew Parish, Jamaica, 12.I. 1971, R. P. Korf et al. (CUP-MJ-400, 402, 407).

45. coprotus lacteus (Cke. \& Phill.) Kimb., Luck-Allen, \& Cain, 
Canad. J. Bot. 50: 965, 1972. Puerto Rico. Substrate: On cow dung. Reported by Kimbrough et al. (14).

46. coprotus ochraceus (Cr. \& Cr.) Larsen, Dan. Bot. Tidsskr. 66: 21 . 1971. Puerto Rico. Substrate: On cow dung. Reported by Kimbrough et al. (14).

JAFNEADELPHUS Rifai.

47. JAFNeAdelphus ?ASPerulus Rifai, Verh. K. ned. Akad. Wet. II 57(3): 91, 1968. Jamaica*. Substrate: On soil and debris.

Specimen examined: On Cecropia leaves and petioles, duff, snail shells, rocks, twigs, etc., Dolphin Head, Hanover Parish, Jamaica, 22.I. 1971, R. P. Korf et al. (CUP-MJ-682).

\section{LAMPROSPORA DeNot.}

48. lamprospora lobata (Berk. \& Curt. in Berk.) Seaver, Mycologia 6: 22, 1914. = Peziza lobata Berk. \& Curt. in Berk., J. Linn. Soc. (Bot.) 10: 365,1868 . Cuba (type locality) Trinidad. Substrate: On soil.

Specimen examined: Fungi Cubensis Wrightiani number 663, on ground, C. Wright number 652 . (FH).

49. LAMbrospora Wrightir (Berk. \& Curt. in Berk.) Seaver, Mycologia 6: 15, 1914. Puerto Rico. Substrate: Soil.

Packets with labels bearing this name are present in the herbarium of the New York Botanical Garden. The specimens were identified by Seaver. No apothecia could be located unfortunately among the remaining pebbles and earth in the envelopes.

\section{LASIOBOLUS Sacc.}

50. lastobolus ciliatus (Schmidt ex Pers.) Boud., Hist. Class. Discom. d'Eur., p. 78, 1907. St. Thomas. Substrate: On animal dung.

Based on Seaver and Chardón's report of Lasiobolus equinus which, according to Rifai (27), is identical to the above named species.

octospora Hedw. ex S. F. Gray emend. Korf

51. octospora leucoloma Hedw. ex S. F. Gray, Nat. Arr. Br. Pl. 1:667, 1821. Puerto Rico. Substrate: Soil.

The specimen upon which this report is based is referable to $O$. leucoloma, although badly preserved. Specimen examined: On soil, Puerto Rico, Jan. 24 to April 5, 1923, F. J. Seaver and C. E. Chardón (NY).

\section{PHAEDROPEZIA Le Gal}

52. Phatedropezia flavida (Berk. \& Curt.) Le Gal, Prodr. Flore Mycol. Madagascar 4: 185, 1953. Puerto Rico*, Trinidad. Substrate: On plant debris. 
Reported by Dennis (9) and Le Gal (16) from Trinidad. Identification of this and the following species are tentative as species delimitations of Caribbean representatives of Phaedropezia are not clear. The author has a monograph of this genus in preparation. Specimen examined: On soil and debris on clay bank, Mayagüez Zoo, Mayagüez, Puerto Rico, 27.VIII. 1972, D. H. Pfister and Cathleen Pfister (D. H. P. 419).

53. Phaedropezia flavotingens (Berk. \& Br.) Le Gal, Bull. Jard. Bot. Brux. 29: 96, 1959. Dominica. Substrate: On soil and plant debris.

Reported by Pfister (17) from Dominica. The specimen is referable probably to $P$. flavida.

PSILOPEZIA Berk.

54. PSILOPEZia Nummularia Berk., Hooker's Lond. J. Bot. 6: 325, 1847. Trinidad. Substrate: On rotten wood.

Reported by Dennis (9) under the name P. juruensis P. Henn. According to Pfister (21), however, the species is properly referred to P. nummularia.

\section{PULvinula Boud.}

55. pulvinula consteldatio (Berk. \& Br.) Boud., Hist. Class. Discom. d'Eur., p. 70, 1907. Jamaica*. Substrate: On soil.

Specimens examined: On soil, Traveler's Rest, Silver Hill Gap on the border of Portland and St. Andrew Parish, elev. 3,000-3,250 feet, 8.I. 1971, R. P. Korf et al. (CUP-MJ-103); trail between Holywell and source of Wag Water River, St. Andrew Parish, 1.I. 1971, R. P. Korf et al. (CUP-MJ-200); on wet soil near army camp, Newcastle, St. Andrew Parish, 17.I. 1971, R. P. Korf et al. (CUP-MJ-561); on soil, trail from Whitfield Hall to Portland Gap to Blue Mt., border of St. Thomas and Portland Parishes, 17.I. 1971, R. P. Korf et al. (CUP-MJ-593); on soil among moss, trail from Whitfield Hall to Portland Gap, to Blue Mt., border of St. Thomas and Portland Parishes, 17.I. 1971, R. P. Korf et al. (CUP-MJ-577).

56. pulvinula globifera (Berk. \& Curt.) Le Gal, Prodr. Flore Mycol. Madagascar 4: 94, 1953. Cuba (type locality), Jamaica, Puerto Rico, Trinidad. Substrate: On clay soil.

The collections from Puerto Rico were described and illustrated by Pfister (18).

57. PUlvinula salmonicolor (Seaver) Pfister, Phytologia 24: 211, 1972. Puerto Rico (type locality). Substrate: On soil.

\section{PYRONEMa Carus}

58. Pyronema OMPhalodes (Bull. ex St.-Amans) Fuckel, Jarb. Nass. Ver. Nat. 23-24: 319, 1870. Guadeloupe, Puerto Rico, St. Croix, Trinidad. Substrate: Burned areas. 
The species has been reported under this name as well as under its synonym $P$. confluens (Pers. ex Pers.) Tul.

\section{RHIZOBLEPHARIA Rifai}

59. RHizoblepharia NeOTropica Erb \& Korf, Phytologia 24: 12, 1972. Jamaica. Substrate: On soil.

\section{scutellinia (Cooke) Lamb.}

The genus Scutellinia contains a considerable number of species and lacks a comprehensive monograph. Numerous species are listed below under names originally assigned to them. No attempt has been made thus far to distinguish between species apparently differing only slightly from each other.

60. scutellinia asperrima (Seaver) Le Gal, Bull. Jard. Bot. Brux. 29: 93, 1959. Trinidad, Cuba. Substrate: On rotten wood.

61. scutellinia barbata Mass., J. Bot. Br. Fl. 30: 161, 1892. Cuba, Puerto Rico. Substrate: On rotten wood.

62. scutellinia cubensis (Berk. \& Curt. in Berk.) Gamundi, Contr. Cient. Univ. B. Aires, Ser. Bot. 1 (2): 84, 1956. Bahamas, Cuba (type locality), Jamaica, Puerto Rico, Trinidad. Substrate: On rotten wood.

This is the most frequently identified and reported species of the genus in the Caribbean. It probably merges along with other species into S. scutellata.

63. scutellinia erinacea (Schw.) Kuntze, Revis. Gen. Pl. 2: 869, 1891. Jamaica*, Puerto Rico, Trinidad. Substrate: On rotten wood.

This species is readily characterized by its smooth ascospores. Specimen examined: On wood, along Sulphur River, above Bath Fountain Hotel, St. Thomas Parish, elev. 500 feet, Jamaica, R. P. Korf et al. (CUP-MJ-466).

64. sCUTELIINIA HIRTA (Schum. ex Fr.) Cooke, Mycographia, p. 71, 1879. Cuba, Guadeloupe. Substrate: On dead wood, earth and stones.

These reports are based on the identifications of Berkeley (5) and Duss (12).

65. scutellinia scutellata (L. ex Fr.) Lamb., Fl. Mycol. Belg. Suppl. 299, 1887. Grenada, Puerto Rico. Substrate: On rotten wood, bark, soil, and other debris.

Most of the species of Scutellinia listed herein probably should be referred here.

66. "PezizA" stictica Berk. \& Curt. in Berk., J. Linn. Soc. (Bot.) 10: $367,1868$.

Examination of the specimen below indicates it is a species of Scutellinia. As this genus already is overburdened with imperfectly known species, little need exists for another combination. Specimen examined: On the 
ground by the side of paths, June, Cuba, C. Wright (643), Fungi Cubensis Wrightiani number 677 (FH).

67. scutellinia texensis (Berk. \& Curt.) Le Gal, Prodr. Flore Mycol. Madagascar 4: 133, 1953. Grenada. Substrate: On rotten wood.

68. scutellinia trechispora (Berk. \& Br.) Lamb., Fl. Mycol. Belg. Suppl. 299, 1887. Jamaica. Substrate: On soil and debris.

\section{TRICHARINA Eckblad}

69. tricharina Gilva (Boud.) Eckbl., Nytt Mag. Bot. 15 (1-2): 60, 1968. Jamaica*. Substrate: On soil.

Specimen examined: On soil, near Dick's Pond, west of Hardwar Gap, near Holywell Recreation Area, St. Andrew Parish elev. 2,800-3,000 feet, Jamaica, 11.I. 1971, R. P. Korf et al. (CUP-MJ-330).

TRIChophafa Boud.

70. trichophaea ?gregaria (Rehm) Boud., Hist. Class. Discom. d'Eur., p. 60, 1907. Jamaica*. Substrate: On soil.

Specimen examined: On clay bank, Cinchona Botanical Gardens, St. Andrew Parish, elev. 4,750 feet, 8.I. 1971, R. P. Korf et al. (CUP-MJ-41).

\section{Helvellaceae}

helvella L. ex Fr.

71. Helvella atra Holmskj. ex Fr., Syst. Mycol. 2: 19. 1822. Jamaica. Substrate: On soil.

This and the species following were reported by Dennis (9).

72. helvella Pezizoides Afz. ex Fr., Syst. Mycol. 2: 20, 1822. Jamaica. Substrate: On soil.

Morchellaceae

\section{MORCHELLA St.-Amans}

73. morchella esculenta L. ex St.-Amans, Fl. Argen. 591. 1821. Cuba (fide Berkeley, 1868). Substrate: On burnt soil.

\section{DISCUSSION}

Although research on the Discomycete flora of the Caribbean is in preliminary stages at this time, a few distributional trends have become apparent. Certain families are scarcely represented. Notably lacking are members of the Morchellaceae and Helvellaceae. Although each family is represented, it seems clear these families reach greatest prevalence and diversity in temperate rather than in tropical regions. Most Pezizales which form large sized ascocarps are found in these families. 
Members of the suborder Sarcoscyphineae are most common in the West Indies and occur in the Tropics in general. In fact other than in the Sarcoscyphineae it is difficult to find any of the Pezizales which have more tropical than temperate members. As a general trend, it seems the suborder Pezizineae diversified evolutionarily in temperate regions while the Sarcoscyphineae diversified in the Tropics.

Certain distributional patterns and substrate preferences also reinforce this idea. The Sarcoscyphineae are associated with wood. The Pezizineae sometimes are associated with wood but many times grow on soil or animal excrement. A dearth of organically rich soils in the Tropics may provide an immediate reason for the lack of the soil inhabiting fungi.

Another generalization: Altitudinal increase increases the number of species, as can be demonstrated by distributional patterns of West Indian Pezizales. An analysis of the reports presented herein indicates that increase in species numbers frequently is due to a prevalence of cosmopolitan or North Temperate species at higher altitudes.

One could postulate hypothetically that the Pezizineae originated or evolved in temperate regions and cosmopolitan species now occurring in the Tropies invaded more recently, while the Sarcoscyphineae most certainly had a Tropical origin. Certain genera of the Pezizineae, such as Phadropezia, may be exceptions.

\section{SOME SYNONYMS AND EXCLUDED SPECIES}

The following is a summary of new and old synonyms appearing in this checklist, providing a cross reference to the more recent names. A few species also are listed originally reported erroneously as belonging to the order Pezizales or doubt exists as to their exact identities.

Ascobolus magnificus Dodge $=A$. scatigenus (Berk. \& Curt.) Brumm.

Ascobolus major Berk. \& Curt. = A. scatigenus

Cookeina tetraspora Seav. = Nanoscypha tetraspora (Seav.) Denison

Discina epixyla Pat. = Cookeina venezuelae (Berk. \& Curt.) Le Gal

Discina martinicae Pat. = Phillipsia domingensis (Berk.) Berk.

Galactinia auriformis Pat. ex Le Gal = Peziza taeniospora Pfister.

Humaria cookeina Seav. = Hymenoscyphus cookeina (Seav.) Tewari \& Khare

Humaria guadelupensis Pat. = Aleuria bicucullata Boud.

Humaria phyllogena Seav. = ?Nanoscypha

Lasiobolus equinus (Müll. ex S. F. Gray) Karst = Lasiobolus ciliatus (Schmidt ex Pers.) Boud.

Peziza adnata Berk. \& Curt. = Pachyella adnata (Berk. \& Curt.) Pfister

Peziza albo-tecta Berk. \& Curt. = a lichen

Peziza bella Berk. \& Curt. = Nanoscypha bella (Berk. \& Curt.) Pfister 
Peziza crispata Berk. \& Curt. = Phillipsia crispata (Berk. \& Curt.) Le Gal

Peziza dochmia Berk. \& Curt. = Aurophora dochmia (Berk. \& Curt.) Rifai

Peziza hirneoloides Berk. \& Curt. = Phillipsia hirneoloides (Berk. \& Curt.) Berk., cfr. Aurophora

Peziza hirneoloides Berk. \& Curt. var. contorta Pat. in Duss = Phillipsia domingensis (Berk.) Berk.

Peziza hystrix Berk. = Cookeina tricholoma (Mont.) O. Kuntze

Peziza inaequalis Berk. \& Curt. = Phillipsia inaequalis (Berk. \& Curt.) Berk.

Peziza leptopus Pers. in Lév. = Cookeina sulcipes (Berk.) O. Kuntze

Peziza lobata Berk. \& Curt. = Lamprospora lobata (Berk. \& Curt.) Seav.

Peziza melanopus Berk. \& Curt. = inoperculate discomycete

Peziza monilifera Berk. \& Curt. = ?Pyronemella, cfr. Tewari and Pant (26).

Peziza scatigena Berk. \& Curt. = Ascobolus scatigenus (Berk. \& Curt.) Brumm.

Peziza subgranulata Berk. \& Curt. = ?Coprobia

Peziza venezuelae Berk. \& Curt. in Cooke var. antillarum Pat. in Duss = Phillipsia domingensis (Berk.) Berk.

Peziza wrightii Berk. \& Curt. = Lamprospora wrightii (Berk. \& Curt.) Seav.

Psilopezia mirabilis Berk. \& Curt. = Alerodiscus

Rhizina spongiosa Berk. \& Curt. = Galiella spongiosa (Berk. \& Curt.) Pfister

Sarcoscypha carminea Pat. = Phillipsia carminea (Pat.) Le Gal, cfr. Aurophora

\section{SUMMARY}

A total of $\mathbf{7 3}$ species in $\mathbf{6}$ families of the Pezizales are listed herein as occurring in the Caribbean. The records of occurrence are based on recent collections, published accounts, and material deposited in various herbaria. Several species described from Guadeloupe by Patouillard are synonymized based on type studies. New depositions are provided for several species described by Seaver and by Berkeley and Curtis. A list of excluded species and synonyms is provided. The following new combinations are proposed: Nanoscypha bella, $N$. waterstonii, and Galiella spongiosa. A new name, Peziza taeniospora, is also proposed.

\section{RESUMEN}

Un total de 73 especies pertenecientes a 6 familias del orden de los pezizales han sido informados en la región del Caribe. Estos informes se basan en colecciones recien- 
tes, trabajos publicados y material depositado en varios herbarios. En varias especies informadas de Guadalupe y descritas por Patouillard existe sinonimia basada en estudios del tipo. Además se mencionan nuevos lugares en que están depositadas varias especies descritas por Seaver y por Berkeley y Curtis. Se incluye una lista de las especies excluidas y los sinónimos. Se proponen las siguientes nuevas combinaciones: Nanoscypha bella, $N$. waterstonii y Galiella spongiosa. También se propone un nuevo nombre, Peziza taeniospora.

\section{LITERATURE CITED}

1. Baker, R. E. D., and Dale, W. T., Fungi of Barbados and the Windward Islands, CMI Mycological Papers 25, 1948.

2. - and - Fungi of Trinidad and Tobago, CMI Mycological Papers 33, 1951.

3. Benjamin, C. R., and Slot, A., Fungi of Haiti, Sydowia 23: 125-63, 1969.

4. Berkeley, M. J., Enumeration of some fungi from Santo Domingo, Ann. Mag. Nat. Hist. II. 9: 201-2, 1852.

5. - On a collection of fungi from Cuba. Part II, including those belonging to the Gasteromycetes, Coniomycetes, Hyphomycetes, Phycomycetes, and Ascomycetes, J. Linn. Soc. (Bot.) 10: 280-392, 1868.

6. Ciferri, R., Mycofiora Domingensis Integrata, Quaderno 19: 1-539, 1961.

7. Denison, W. C., Central American Pezizales. III. The genus Phillipsia, Mycologia 61: 289-304, 1969.

8. - Central American Pezizales. IV. The genera Sarcoscypha, Pithya, and Nanoscypha, Mycologia 64: 609-23, 1972.

9. Dennis, R. W. G., Operculate Discomycetes from Trinidad and Jamaica, Kew Bull. 9: 409-21, 1954.

10. - Some inoperculate Discomycetes of Tropical America, Kew Bull. 9:289-348, 1954.

11. —, Fungus flora of Venezuela and adjacent countries, J. Cramer, 532 pp., 1971.

12. Duss, P. R., Enumération Méthodique des Champignons recueillis à la Guadeloupe \& à la Martinique, Lons-Sauvier, 94 pp. 1903.

13. Kimbrough, J. W., Luck-Allen, E. R., and Cain, R. F., Iodophanus, the Pezizeae segregate of Ascophanus (Pezizales), Amer. J. Bot. 56(10): 1,187-202, 1969.

14. - -,- , and - North American species of Coprolus (Thelebolaceae: Pezizales) Canad. J. Bot. 50: 956-71, 1972.

15. Korf, R. P., Synoptic key to the genera of the Pezizales, Mycologia 64: 937-94, 1972.

16. Le Gal, M., Les Discomycètes de Madagascar, Prodr. Fl. Mycol. Madagascar 4: $1-465,1953$.

17. Pfister, D. H., Notes on Caribbean Discomycetes. I. Cytological evidence for the exclusion of Phaedropezia from the Sarcoscyphaceae, Carib. J. Sci. 12(1-2): 39-40, 1972.

18. - Notes on Caribbean Discomycetes. II. Two species of Pulvinula from Puerto Rico, Phytologia 24: 211-15, 1972.

19. - Notes on Caribbean Discomycetes. III. Ascospore germination and growth in culture of Nanoscypha tetraspora (Pezizales, Sarcoscyphineae), Mycologia 65: 952-56, 1973.

20. - Notes on Caribbean Discomycetes. IV. Cookeina venezuelae, C. colensoi and the genus Boedijnopeziza, Phytologia 27 : 55-62, 1973.

21. - The psilopezioid fungi. III. The genus Psilopezia (Pezizales), Amer. J. Bot. 60: 355-65, 1973. 
22. - The psilopezioid fungi. IV. The genus Pachyella (Pezizales), Canad. J. Bot. $51: 1973$.

23. Seaver, F. J., The North American Cup-Fungi (Operculates). Published by the author, New York, N.Y., 284 pp., 1928.

24. - , and Chardón, C. E., Mycology, Scientific Survey of Porto Rico and the Virgin Island 8(1): 1-208, 1926.

25. Stevenson, J. A., A check list of Puerto Rican fungi and a host index, J. Agr. Univ. P. R. 2: 125-264, 1918.

26. Tewari, V. P., and Pant, D. C., Taxonomic study of Pyronemella monilifera, Canad. J. Bot. 46 : 1,341-43, 1968.

27. Rifai, M. E., The Australasian Pezizales in the Herbarium of the Royal Botanic Gardens Kew. Verh. K. ned. Akad. Wet. II 57 (3): 1-295, 1968.

28. van Brummelen, J., A world-monograph of the genera Ascobolus and Saccobolus (Ascomycetes, Pezizales), Persoonia, Suppl. 1: 1-260, 1967.

\section{APPENDIX}

TABLE 1.-West Indian fungus floras and the number of species of Pezizales recorded in each reference

\begin{tabular}{|c|c|}
\hline Author(s) & $\begin{array}{l}\text { Number of Pezizales } \\
\text { listed }\end{array}$ \\
\hline \multicolumn{2}{|l|}{ Baker and Dale $(1)^{1}$} \\
\hline Barbados & 0 \\
\hline \multicolumn{2}{|l|}{ Baker and Dale (2) } \\
\hline Trinidad and Tobago & 9 \\
\hline \multicolumn{2}{|l|}{ Benjamin and Slot (3) } \\
\hline Haiti & 1 \\
\hline \multicolumn{2}{|l|}{ Berkeley (4) } \\
\hline Dominican Republic & 2 \\
\hline \multicolumn{2}{|l|}{ Berkeley (5) } \\
\hline Cuba & 19 \\
\hline \multicolumn{2}{|l|}{ Ciferri (6) } \\
\hline Dominican Republic & 8 \\
\hline \multicolumn{2}{|l|}{ Dennis (9) } \\
\hline Trinidad and Jamaica & 19 \\
\hline \multicolumn{2}{|l|}{ Duss (12) } \\
\hline Guadeloupe and Martinique & 10 \\
\hline \multicolumn{2}{|l|}{ Seaver and Chardón (24) } \\
\hline Puerto Rico and the Virgin Islands & 24 \\
\hline
\end{tabular}

1 Numbers in parentheses refer to Literature Cited. 
TABLe 2.-Synopsis of the West Indian Pezizales

\begin{tabular}{|c|c|}
\hline \multicolumn{2}{|c|}{ SARCOSCYPERIEAE } \\
\hline Sarcoscyphaceace & Sarcosomalacese \\
\hline $\begin{array}{l}\text { Aurophora.dochmia } \\
\text { Cookeinia sulcipes } \\
\text { C. tricholoma } \\
\text { C. venezuelae } \\
\text { Nanoscypha bella } \\
\text { N. teiraspora } \\
\text { Humaria phyllogena } \\
\text { Phillipsia carminea } \\
\text { P. chardoniana } \\
P . \text { crispata } \\
P . \text { domingensis } \\
P . \text { gigantea } \\
P . \text { hirneoloides } \\
P . \text { inaequalis } \\
\text { Sarcoscypha occidentalis }\end{array}$ & $\begin{array}{l}\text { Galiella spongiosa } \\
\text { Plectania campylospora } \\
\text { P. melastoma } \\
\text { P. rhylidia }\end{array}$ \\
\hline
\end{tabular}

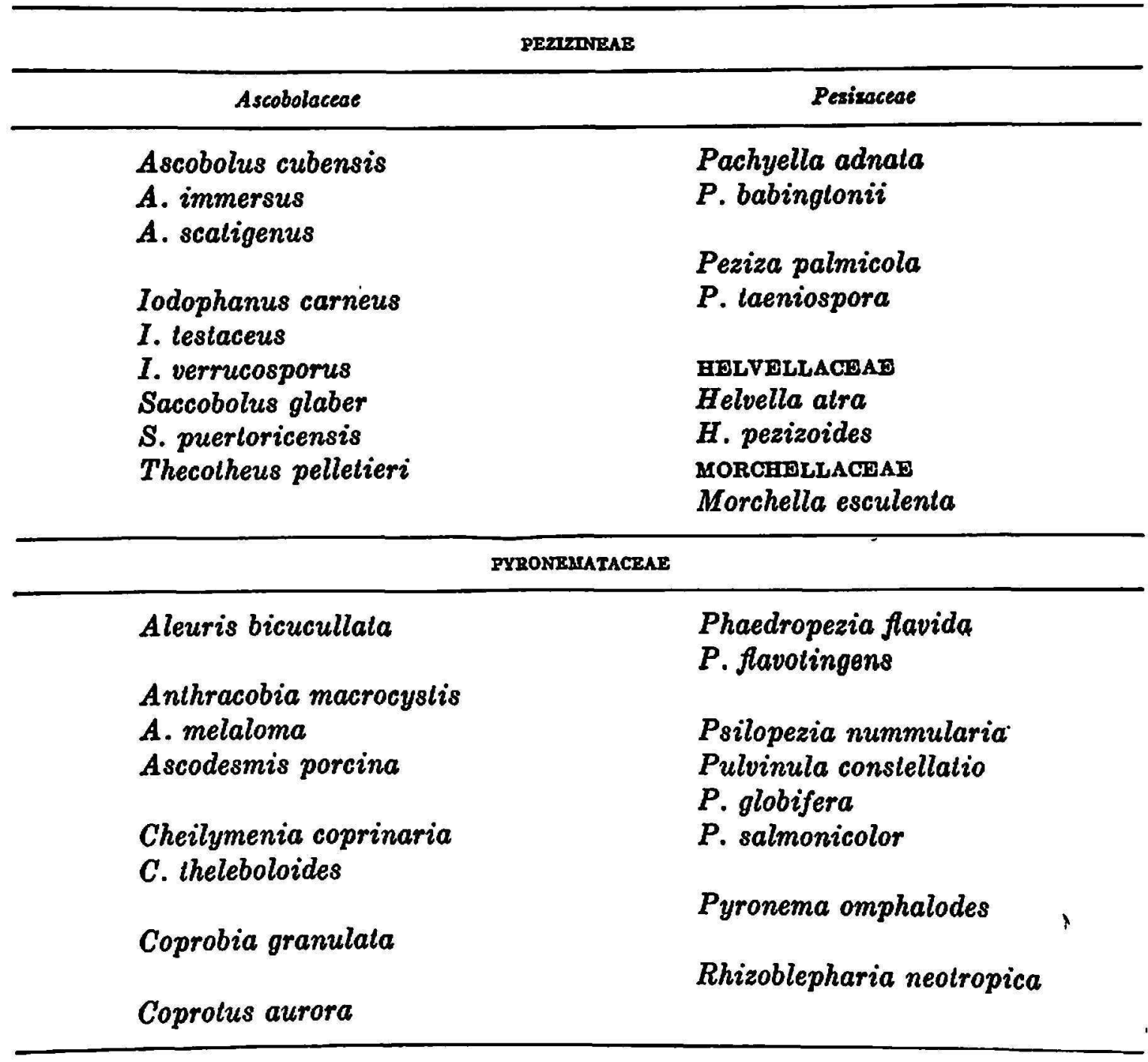


TABLE 2.-(Continued)

\begin{tabular}{ll}
\hline & PYRONEMATAOEa (Continued) \\
\hline C. dextrinoides & Scutellina asperrima \\
C. disculus & S. barbata \\
C. lacteus & S. cubensis \\
C. ochraceus & S. erinacea \\
& S. hirta \\
Jafneadelphus asperulus & S. scutellata \\
& "Peziza" stictica \\
Lamprospora lobata & S. texensis \\
L. wrightii & S. trechispora \\
Lasiobolus cilialus & Tricharina gilva \\
Octospora leucoloma & Trichophaea gregaria \\
\hline
\end{tabular}

